\title{
KNOWLEDGE AND AWARENESS OF TUBERCULOSIS AMONG PULMONARY TUBERCULOSIS PATIENTS IN A RURAL AREA OF WEST BENGAL
}

\author{
Pramanik D1, Ghosh JR ${ }^{2}$ \\ ${ }^{1}$ TBCV, Rampurhat TU, West Bengal, India \\ 2 Visva-Bharati University, Santiniketan, West Bengal, India
}

\begin{abstract}
Introduction: India has more new tuberculosis (TB) cases annually than any other country and contributing of about twenty percent to the global burden of TB. The objective of the present study was to understand the knowledge and awareness of TB among adult male pulmonary TB patients in a rural area of West Bengal.

Methodology: The present cross-sectional study was carried out among the TB patients registered under the Revised National Tuberculosis Control Programme (RNTCP). A structured questionnaire was used for data collection.

Results: The mean age of the study participants was 41.46 (14.3) years.52\% of the subjects never heard of TB before diagnosis of their disease. Majorities of the participants thought that smoking and chewing tobacco was the cause of TB. With regard to the mode of spread, $21 \%$ thought that TB spread through unclean food and water followed by through sharing materials for drink (21\%). Most of the participants were unaware or had no idea about the fact that transmission of TB is preventable. With regard to the occurrence of TB in life time, $64 \%$ had no idea. With regard to the curability of TB, $38 \%$ said that it is curable and majorities $(60 \%)$ said don't know, $40 \%$ subjects thought that good food and drinking water can reduce the chance of getting TB.

Conclusion: This study showed that lack of knowledge and misconceptions regarding TB were widespread among the TB patients. Thus, the present study emphasizes the need for health education programmes to improve knowledge, awareness and removing misconceptions about TB.
\end{abstract}

Key words: Awareness, Knowledge, Pulmonary tuberculosis, West Bengal

\section{INTRODUCTION}

Tuberculosis (TB) has reached epidemic proportions in many developing countries including India. ${ }^{1}$ India has more new TB cases annually than any other country with a contribution of over twenty percent to the global burden of TB. ${ }^{2}$ Among different types, pulmonary TB is one of the leading causes of adult mortality. ${ }^{3}$ Studies also demonstrated that the prevalence of TB was more common among men than women of economically

\section{Correspondence:}

Dr. Jyoti Ratan Ghosh

Assistant Professor

Department of Anthropology, Visva-Bharati University,

Santiniketan-731235, West Bengal, India

E mail: jrghosh@rediffmail.com;

jrghosh@visva-bharati.ac.in productive age groups, ${ }^{4}$ indicating variation in infection and progression of disease. ${ }^{5}$

Study shows that HIV positive individuals are more susceptible to develop TB compared to HIV negative individuals and it is the leading cause of death among HIV positive individuals. ${ }^{6}$ The association of pulmonary TB with diabetes mellitus. ${ }^{7,8}$ and rheumatoid arthritis ${ }^{9}$ is also well established. Study also shows that TB patients had a significantly higher risk of developing chronic kidney disease than the controls. ${ }^{10}$

Since the introduction of National Tuberculosis Control Programme (NTP) in 1962, the Government of India has taken different steps to controlling TB on a mass basis. ${ }^{11,12}$ However, the lack of awareness regarding TB impeding progress toward TB control. Because, the incidence of TB was inversely associated with increasing awareness. ${ }^{13,14}$ Moreover, lack of awareness 
can worsen the epidemiological situation by increasing drug resistant patients, who may increase the risk of infection with drug-resistant bacilli. ${ }^{12}$

Literature review revealed that some studies in India have been done to understand the knowledge and awareness about TB both in patient ${ }^{15-17}$ and in general populations. ${ }^{18,19}$ However, to best of our knowledge, study related to knowledge and awareness about TB among TB patients of rural areas of West Bengal is yet to be made. With this view of context, the objective of the present study was to understand the knowledge and awareness of TB among adult male pulmonary TB patients in a rural area of West Bengal.

\section{METHODOLOGY}

The present cross-sectional study was carried out among one hundred adult male pulmonary TB patients, selected at random from the patients registered under Revised National Tuberculosis Control Programme (RNTCP) of Rampurhat Tuberculosis Unit (TU), West Bengal, about $250 \mathrm{~km}$. from Kolkata city. Informed consent was obtained from each participant before commencement of the study. The participants in the present study were restricted in male because studies revealed that the prevalence of TB was higher in males than females. ${ }^{20}$ Moreover, a recent study ${ }^{21}$ based on NFHS-2 and NFHS-3 data demonstrated that the prevalence of TB had significantly declined in female, but not in male.

A structured questionnaire was used for data collection. The questionnaire was first pilot tested and after a few modifications the questionnaire was implemented. The questionnaire consisted of two sections; first section was about the subject's socio-economic characteristics including age, sex, education, occupation, monthly household income etc. Second section was about the knowledge and awareness on TB like heard of TB disease, cause of transmission, symptoms, parts of the body affected by TB bacilli, etc. Statistical analyses were performed using SPSS software version 9.0 (Statistical Package for Social Science, SPSS Inc, Illinois, USA).

\section{RESULTS}

Mean age of the study participants was 41 years. The average monthly household income of the participants was Rs. 2548 (1627). Characteristics of the studied population are presented in table 1. It shows that majority $(84 \%)$ of the study participants were married.
With regard to the educational status, $59 \%$ participants were able to read and write, $38 \%$ were illiterate, $3 \%$ were only able to read. The distribution of occupation indicated that most of the participants occupation were either daily labor $(35 \%)$ or agriculture labor $(33 \%)$, followed by business (12\%) and others including driver, service, pastoralist (3\%). However, $17 \%$ individuals were unemployed. The result also revealed that most $(72 \%)$ of the participants are residing in the study area since birth.

\begin{tabular}{|l|l|c|}
\hline $\begin{array}{l}\text { Table 1. Characteristics of the studied } \\
\text { population }\end{array}$ & Percentage \\
\hline Characters & $\begin{array}{l}\text { Specified } \\
\text { characters }\end{array}$ & 84 \\
\hline Marital status & Married & 14 \\
\cline { 2 - 3 } & Single & 59 \\
\hline Education & Reade and write & 3 \\
\cline { 2 - 3 } & Read only & 38 \\
\cline { 2 - 3 } & Illiterate & 35 \\
\hline Occupation & Daily labor & 33 \\
\cline { 2 - 3 } & Agriculture labor & 17 \\
\cline { 2 - 3 } & Unemployed & 3 \\
\cline { 2 - 3 } & Business & 72 \\
\cline { 2 - 3 } & Others & 28 \\
\hline Duration of \\
residence
\end{tabular}

Knowledge and awareness about TB in the studied population are presented in table 2. It revealed that, $52 \%$ of the subjects never heard of TB disease before diagnosis of their disease. When they were asked about the source of information about TB, 26\% individuals replied health worker, $11 \%$ replied patient, followed by friend $(6 \%)$, family member $(3 \%)$ and, media and neighbor $1 \%$ each as a source of information about TB. With regard to the cause of TB, $19 \%$ participants think that smoking and chewing tobacco was the cause of TB. $17 \%$ participants think that poor nutrition was the cause of TB, followed by, drinking alcohol $(12 \%)$, cold air $(9 \%)$, dust $(8 \%)$, shortage of food $(7 \%)$, bacteria/germ $(6 \%)$, drinking raw milk $(3 \%)$, evil eye $(2 \%)$ and work load $(2 \%)$. However, $15 \%$ subjects had no idea about the cause of TB. When 
participants were asked about the symptoms of TB, $21 \%$ answered that cough for 2 or more weeks was the symptom of TB. However, $17 \%$ participants answered that sputum with blood was the symptom of TB. 15\% participants thought that cough for 2 or more weeks, sputum with blood and weight loss were the symptom of TB, followed by fever and sweat at night $(14 \%)$, cough for 2 or more weeks and fever and sweat $(6 \%)$, fever and sweat at night and sputum with blood (5\%), chest pain (4\%), cough for 2 or more weeks and chest pain $(4 \%)$, sputum with blood and chest pain $(3 \%)$, fever and sweat at night and chest pain (3\%), sputum with blood, weight loss and loss of appetite (3\%), weight loss and chest pain (2\%), cough for 2 or more weeks, fever and sweat at night and chest pain (2\%), and cough for 2 or more weeks, loss of appetite and chest main (1\%). With regard to the mode of spread, $21 \%$ thought that TB spread through unclean food and water. Another $21 \%$ thought that the mode spread was through sharing materials for drink, followed by through cough, sneeze and breadth (14\%), drinking raw milk $(11 \%)$, through sharing materials for feeding $(10 \%)$, heredity $(8 \%)$, through contact with patient $(4 \%)$. However, $11 \%$ subjects have no idea about the mode of spread. When the participants were asked about the transmission of TB preventable or not, only $15 \%$ answered yes and $62 \%$ answered as don't know. When the subjects were asked about the source of information on TB treatment, $55 \%$ replied that the source of information was health workers, $30 \%$ replied as patient, $14 \%$ replied as family and $1 \%$ replied the source of information was media. With regard to the duration of TB treatment, $66 \%$ replied that the duration of TB treatment was 6 months, $10 \%$ replied 7 months, $11 \%$ replied $\geq 8$ months, $5 \%<6$ months. When the participants were asked about the occurrence of TB in life time, $29 \%$ replied that TB can re-occurred, $7 \%$ replied that TB occurs only once in life time. $64 \%$ replied that they don't know. With regard to the organs affected by TB, $72 \%$ thought that only lung is affected by TB and $26 \%$ replied don't know. With regard to the curability of TB, $38 \%$ said that it is curable. With regard to the question, what reduces the chance of getting TB, $40 \%$ subjects replied that good food and drinking water can reduce the chance of getting TB, $10 \%$ subjects replied that good environment can reduce the chance of getting TB, $15 \%$ subjects replied that avoiding of smoking and alcohol can reduce the chance of getting TB, followed by drink lots of water $(3 \%)$, avoid dust $(3 \%)$, supplementary nutrition $(2 \%)$, take care of cold (
$2 \%$, keep distance from TB patient $(2 \%)$, protection against germ $(1 \%)$, take care of health $(1 \%)$.

\begin{tabular}{|c|c|c|}
\hline Characters & $\begin{array}{l}\text { Specified } \\
\text { characters }\end{array}$ & $\%$ \\
\hline \multirow{2}{*}{$\begin{array}{l}\text { Heard of TB, } \\
\text { before diagnosis }\end{array}$} & No & 52 \\
\hline & Yes & 48 \\
\hline \multirow{6}{*}{$\begin{array}{l}\text { Source of } \\
\text { information about } \\
\text { TB }\end{array}$} & Health worker & 26 \\
\hline & Patient & 11 \\
\hline & Friend & 6 \\
\hline & Family member & 3 \\
\hline & Media & 1 \\
\hline & Neighbor & 1 \\
\hline \multirow{11}{*}{ Cause of TB } & $\begin{array}{l}\text { Smoking and } \\
\text { chewing tobacco }\end{array}$ & 19 \\
\hline & Poor nutrition & 17 \\
\hline & Drinking alcohol & 12 \\
\hline & Cold air & 9 \\
\hline & Dust & 8 \\
\hline & Shortage of food & 7 \\
\hline & Bacteria/Germ & 6 \\
\hline & Drinking raw milk & 3 \\
\hline & Evil eye & 2 \\
\hline & Work load & 2 \\
\hline & Don't know & 15 \\
\hline \multirow{6}{*}{ Symptoms of TB } & $\begin{array}{l}\text { Cough for } 2 \text { or more } \\
\text { weeks }\end{array}$ & 21 \\
\hline & Sputum with blood & 17 \\
\hline & $\begin{array}{l}\text { Fever and sweat at } \\
\text { night }\end{array}$ & 14 \\
\hline & $\begin{array}{l}\text { Cough for } 2 \text { or more } \\
\text { weeks, sputum with } \\
\text { blood and weight } \\
\text { loss }\end{array}$ & 15 \\
\hline & $\begin{array}{l}\text { Cough for } 2 \text { or more } \\
\text { weeks and fever } \\
\text { and sweat }\end{array}$ & 6 \\
\hline & $\begin{array}{l}\text { Fever and sweat at } \\
\text { night and sputum }\end{array}$ & 5 \\
\hline
\end{tabular}




\begin{tabular}{|c|c|c|}
\hline & with blood & \\
\hline & Chest pain & 4 \\
\hline & $\begin{array}{l}\text { Cough for } 2 \text { or more } \\
\text { weeks and Chest } \\
\text { pain }\end{array}$ & 4 \\
\hline & $\begin{array}{l}\text { Sputum with blood } \\
\text { and chest pain }\end{array}$ & 3 \\
\hline & $\begin{array}{l}\text { Fever and sweat at } \\
\text { night and chest pain }\end{array}$ & 3 \\
\hline & $\begin{array}{l}\text { Weight loss and } \\
\text { chest pain }\end{array}$ & 2 \\
\hline & $\begin{array}{l}\text { Sputum with blood, } \\
\text { weight loss and loss } \\
\text { of appetite }\end{array}$ & 3 \\
\hline & $\begin{array}{l}\text { Cough for } 2 \text { or more } \\
\text { weeks, loss of } \\
\text { appetite and chest } \\
\text { main }\end{array}$ & 1 \\
\hline & $\begin{array}{l}\text { Cough for } 2 \text { or more } \\
\text { weeks, fever and } \\
\text { sweat at night and } \\
\text { chest pain }\end{array}$ & 2 \\
\hline & Through unclean & 21 \\
\hline & Through sharing & 21 \\
\hline & Through cough, & 14 \\
\hline Mode of snread & Drinking raw milk & 11 \\
\hline & Don't know & 11 \\
\hline & Through sharing & 10 \\
\hline & Heredity & 8 \\
\hline & Through contact & 4 \\
\hline & Yes & 15 \\
\hline $\begin{array}{l}\text { Iransmission of } \\
\text { TB preventable }\end{array}$ & No & 23 \\
\hline & Don't know & 62 \\
\hline & Health worker & 55 \\
\hline Source of & Patient & 30 \\
\hline treatment & Family & 14 \\
\hline & Media & 1 \\
\hline & 6 months & 66 \\
\hline & 7 months & 10 \\
\hline $\begin{array}{l}\text { Duration of } \\
\text { treatment }\end{array}$ & $\geq 8$ months & 11 \\
\hline & Don't know & 8 \\
\hline & $<6$ months & 5 \\
\hline
\end{tabular}

SAARC J TUBER LUNG DIS HIV/AIDS, 2015 XII(2)

\begin{tabular}{|c|c|c|}
\hline \multirow{3}{*}{$\begin{array}{l}\text { Occurrence of TB } \\
\text { in life time }\end{array}$} & Re-occurred & 29 \\
\hline & Only once & 7 \\
\hline & Don't know & 64 \\
\hline \multirow{4}{*}{$\begin{array}{l}\text { Organ effected by } \\
\text { TB }\end{array}$} & Lung & 72 \\
\hline & Don't know & 26 \\
\hline & Bone & 1 \\
\hline & Whole body & 1 \\
\hline \multirow{3}{*}{ Curability of TB } & Yes & 38 \\
\hline & No & 2 \\
\hline & Don't know & 60 \\
\hline \multirow{11}{*}{$\begin{array}{l}\text { What reduces the } \\
\text { chance of getting } \\
\text { TB }\end{array}$} & $\begin{array}{l}\text { Good food and } \\
\text { drinking water }\end{array}$ & 40 \\
\hline & Good environment & 10 \\
\hline & $\begin{array}{l}\text { Avoid smoking and } \\
\text { alcohol }\end{array}$ & 15 \\
\hline & Drink lots of water & 3 \\
\hline & $\begin{array}{l}\text { Supplementary } \\
\text { nutrition }\end{array}$ & 2 \\
\hline & Take care of cold & 2 \\
\hline & Avoid dust & 3 \\
\hline & $\begin{array}{l}\text { Keep distance from } \\
\text { TB patient }\end{array}$ & 2 \\
\hline & $\begin{array}{l}\text { Protection against } \\
\text { germ }\end{array}$ & 1 \\
\hline & Take care of health & 1 \\
\hline & Don't know & 21 \\
\hline
\end{tabular}

\section{DISCUSSION}

Poverty and lack of awareness are considered the most important factors that increase the risk of exposure to TB as well as health-seeking behavior. Moreover, it also affects earlier diagnosis, effective treatment and prevention strategy. ${ }^{14}$ In order to understand the knowledge and awareness on TB among adult male pulmonary TB patients of a rural area of West Bengal, the result revealed that majorities of the subject never heard the disease TB before diagnosis of their TB disease. However, it was $27.6 \%$ in Pakistan who never heard about the disease, before diagnoses of their TB ${ }^{1}$ and $83 \%$ in South West Ethiopia. ${ }^{22}$ 
Primary source of information about TB and its treatment in the present study was health worker, followed by patient. However, the contribution of media in increasing awareness was very low. This was in corroboration with the study by Khan et al. ${ }^{1}$. Contrary to that, health facility was the least source of information while relatives and friends were the most important sources in central Tanzania. ${ }^{3}$

Interestingly, most of the subjects had misconception about the cause of TB, they think that smoking and chewing tobacco, poor nutrition, drinking alcohol, cold air, dust, shortage of food, drinking raw milk, evil eye and work load were the causes of TB. However, very small number of individuals answered that bacteria/germ was the cause of TB. Similarly in a study in Delhi, Singh et al. ${ }^{23}$ reported that only $2.3 \%$ of the participants knew that TB was caused by a germ. Similar to the findings of the present study a previous study in Ethiopia also observed misconceptions about the causative agent of TB in majorities of the participants. ${ }^{14}$ Study in central Tanzania also observed smoking cigarette or tobacco as the most important cause of TB infections. ${ }^{3}$ Smoking as the cause of TB was also perceived by the majorities of South Africans. ${ }^{24}$ The findings of the present study indicated that the subjects had basic awareness about the symptoms of TB, which was comparable to the results of previous studies from West Bengal, ${ }^{12}$ North East Ethiopia, ${ }^{14}$ South West Ethiopia ${ }^{22}$ and Nepal. ${ }^{25}$ The results also demonstrated that the participant's knowledge about the mode of spread of TB varied widely. Most of the participants thought that sociocultural factors like sharing materials for drink and feeding are the mode of spread of the disease. However, some community-based studies showed that social-cultural factors may increase the risk of acquiring TB. ${ }^{26,27}$ Sharing of domestic utensils was also considered as an important modes of TB transmission in central Tanzania. ${ }^{3}$

In contrary to some other studies ${ }^{14,} 28$ most of participants in the present study were either unaware or had no idea about the fact that the transmission of TB is preventable. This was only $10 \%$ in Pakistan, who was not considered TB as a preventable disease. ${ }^{1}$ We also noted that majorities of the participants were aware about the duration of treatment, but had no idea about its occurrence in life time. Similar study by Khan et al. ${ }^{1}$ also observed that only $17 \%$ responders in Pakistan thought that TB occurred only once in a life-time and did not recur for a second time after treatment. The SAARC J TUBER LUNG DIS HIV/AIDS, 2015 XII(2) participant's awareness about the duration of treatment was in corroboration with the study in Tanzania. ${ }^{28}$

It was also observed that most of the participants in the present study thought that only lung is affected by TB. Similar result was observed in the study conducted in Southwest Ethiopia, ${ }^{22}$ where, $91.6 \%$ of the TB suspects thought that the lungs were the most affected part of the body. Majorities of Nepalese people also thought lung as the main part affected by $\mathrm{TB} \cdot{ }^{25}$ Contrary to that, only $23 \%$ Pakistani patients considered lung as the only organ affected by TB. ${ }^{1}$ With regard to the curability of TB, most of the patients had no idea about the curability of TB. Only $38 \%$ said that it is curable. Contrary to that a previous study in Tanzania by Kilale et al. ${ }^{28}$ showed that all respondents in that study knew that TB was a curable disease. Majorities of the TB patients in Nepal also aware that TB is curable disease. ${ }^{29}$ Interestingly,majorities of the TB patients in the present study thought that good food and drinking water can reduce the chance of getting TB, followed by avoiding smoking and alcohol, and good environment.

\section{CONCLUSSION}

This study showed that both lack of knowledge and misconceptions regarding TB were widespread among the TB patients. For example, majority of the subjects never heard the disease TB. A considerable number of the participants had misconceptions about the cause and mode of spread of TB. Most of the participants in the present study were either unaware or had no idea about the fact that the TB is curable and transmission of TB is preventable. Surprisingly, a large number of participants thought that good food and drinking water can reduce the chance of getting TB. Thus, the present study emphasizes the need for health education programmes to improve knowledge, awareness and removing misconceptions about TB. Because, poor knowledge of TB patients concerning their disease may obstacle in effective cure, prevention and control of the disease, and thus will contribute more burden of TB disease in the country. However, the main limitations of the present study are the relatively small sample size, restricted to males, and it is not representative of the Indian population. Further studies are needed in a larger sample for effective planning of TB control and prevention strategies.

\section{Acknowledgements}

The authors are grateful to the all participants. The authors are also grateful to the Department of 
Anthropology, Visva-Bharati for providing all the facilities for conducting this research.

\section{REFERECES}

1. Khan JA, Irfan M, Zaki A, Beg M, Hussain SF, Rizvi N. Knowledge, attitude and misconceptions regarding Tuberculosis in Pakistani patients. The Journal of the Pakistan Medical Association. 2006;56:211-14.

2. Central TB Division. TB India 2011: RNTCP overview 2010, Annual status report. New Delhi, India: Directorate of Health Service, Ministry of Health and Family Welfare; 2011.

3. Mangesho PE, Shayo E, Makunde WH, Keto GBS, Mandara GI, Kamugisha ML et al DRS. Commnity knowledge, attitudes and practices towards tuberculosis and its treatment in Mpwapwa District, central Tanzania. Tanzania Health Research Bulletin. 2007;9:38-43.

4. Kumar G, Jha N, Niraula SR, Yadav DK, Bhattarai $S$ et al PK. Gender based barriers in accessing tuberculosis treatment: A qualitative study from Eastern Nepal. SAARC J Tuber Lung Dis HIVIAIDS. 2013;10(2): 15-20.

5. Ganapathy S, Thomas BE, Jawahar MS, Selvi KJA, Sivasubramaniam and Weiss M. Perceptions of gender and tuberculosis in a South Indian urban community. The Indian J Tuber 2008;55(1):9-14.

6. Molaeipoor L, Poorolajal J, Mohraz M and Esmailnasab $\mathrm{N}$. Predictors of tuberculosis and human Immunodeficiency virus co-infection: A case-control study. Epidemiology and Health. 2014;e2014024.

7. Kant S, Lata H, Natu SM, Mishra AK and Verma NS. Diabetes mellitus with pulmonary tuberculosis - a double trouble. J Ind Med Asso 2013;111(3):187-91.

8. Baghaei $P$, Marjani $M$, Javanmard $P$, Tabarsi $P$ and Masjedi MR. Diabetes mellitus and tuberculosis facts and controversies. Journal of Diabetes and Metabolic Disorder. 2013;12(1):58.

9. Yeh JJ, Wang YC, Sung FC and $\mathrm{Kao} \mathrm{CH}$. Rheumatoid arthritis increases the risk of non-tuberculosis mycobacterial disease and active pulmonary tuberculosis. Plos One. 2014;9(10):e110922.

10. Shen TC, Huang $\mathrm{KY}$, Chao $\mathrm{CH}$, Wang $\mathrm{YC}$, Muo $\mathrm{CH}$, Wei $\mathrm{CC}$, et al. The risk of chronic kidney disease in tuberculosis: A population-based cohort study. Quarterly journal of medicine. 2014;pii:hcu220.

11. Basu $M$ and Das P. Assessment of knowledge regarding tuberculosis in the context of revised national tuberculosis control program among budding doctors. Chronicles of Young Scientists. 2014;5(1):59-64.
12. Kaur B, Samel.P, Kumari R and Garcha MK. A study to assess the knowledge regarding dots therapy among tuberculosis clients at TB sanatorium in Amritsar in a view to develop and distribute an information booklet. International Journal of Education and Applied Research. 4(1):20-24.

13. World Health Organization. The global plan to stop TB, 2006-2015: Actions for life, towards a world free of tuberculosis. Geneva: World Health Organization; 2006.

14. Legesse M, Ameni G, Mamo G, Medhin G, Shawe D, Bjune $G$ and Abebe $F$. Knowledge and perception of pulmonary tuberculosis in pastoral communities in the middle and Lower Awash Valley of Afar region, Ethiopia. BMC Public Health. 2010;10:187.

15. Khalil S, Ahmad E, Khan Z and Perwin N. A study of knowledge and awareness regarding pulmonary tuberculosis patients under treatment for tuberculosis in a rural area of Aligarh - UP. Indian Journal of Community Health. 2011; 23(2):93-95.

16. Das $P$, Basu M, Dutta $S$ and Das D. Perception of tuberculosis among general patients of tertiary care hospitals of Bengal.Lung India. 2012;29(4):319-324.

17. Gopu GS, Rao VB and Vadivet J. Impact of health education on the knowledge of tuberculosis among sputum-positive pulmonary TB patients and their caregivers. The Nursing Journal of India. 2012;103(4):16062.

18. Aparajita DG, Amrita S and Santanu G. Awareness of management of tuberculosis among health workers in a rural area of West Bengal. The Journal of Communicable Diseases. 2008; 40(1):75-77.

19. Datta K, Bhatnagar $T$ and Murhekar M. Private practitioners' knowledge, attitude and practices about tuberculosis, Hooghly district, India.The Indian Journal of Tuberculosis. 2010;57(4):199-206.

20. Kadri AM, Bhagyalaxmi A, Lala MK, Jivrajini $P$, Vidhani $M$ and Patel T. An epidemiological study of prevalence of tuberculosis in the urban slum area of Ahmedabad city. Indian Journal of Community Medicine. 2003;28(3):122-24.

21. Sharma PP, Kumar A and Singh P. A study of gender differentials in the prevalence of tuberculosis based on NFHS-2 and NFHS-3 data. Indian Journal of Community Medicine. 2010;35(2):230-37.

22. Abebe G, Deribew A, Apers L, Woldemichael K, Shiffa $\mathrm{J}$, Tesfaye M, et al. Knowledge, health seeking behavior and perceived stigma towards tuberculosis among tuberculosis suspects in a rural community in Southwest Ethiopia. Plos One. 2010;5(10):e13339. 
23. Singh MM, Bano T, Pagare D, Sharma N, Devi R and Mehra M. Knowledge and attitude towards tuberculosis in a slum community of Delhi. The Journal of Communicable Diseases. 2002;34(3):203-214.

24. Promtussananon $S$ and Peltzer K. Perceptions of tuberculosis: Attributions of cause, suggested means of risk reduction, and preferred treatment in the Limpopo province, South Africa. Journal of Health, Population, and Nutrition. 2005;23(1):74-81.

25. Bhatt $C P$, Bhatt $A B$ and Shrestha B. Nepalese peoples knowledge about tuberculosis. SAARC J Tuber Lung Dis HIVIAIDS.2009;6(2):31-37.

26. Liefooghe R, Baliddawa JB, Kipruto EM, Vermeire C and De Munynck AO. From their own Perspective. A Kenyan community's perception of tuberculosis. Tropical Medicine \& International Health. 1997;2(8):809-21.
27. Mfinanga SG, Mørkve O, Kazwala RR, Cleaveland S, Sharp JM, Shirima $G$ and Nilsen R. Tribal differences in perception of tuberculosis: A possible role in tuberculosis control in Arusha, Tanzania. The International Journal of Tuberculosis and Lung Disease. 2003;7(10):933-41.

28. Kilale AM, Mushi AK, Lema LA, Kunda J, Makasi CE, Mwaseba D, Range NS and Mfinanga GS. Perceptions of tuberculosis and treatment seeking behaviour in llala and Kinondoni municipalities in Tanzania. Tanzania Journal of Health Research. 2008;10(2):89-94.

29. Bhatt $C P$, Bhatt $A B$ and Shrestha $B$. Knowledge of tuberculosis treatment - A survey among tuberculosis patients in (DOTS) program in Nepal. SAARC J Tuber Lung Dis HIVIAIDS. 2010;7(2):10-14. 